\title{
ESTIMATION OF ROAD ROUGHNESS FROM DATA OF ON-VEHICLE MOUNTED SENSORS
}

\section{OCENA NIERÓWNOŚCI DROGOWYCH ZGODNIE Z DANYMI CZUJNIKÓW ZAINSTALOWANYCH NA POJEŹDZIE}

\begin{abstract}
In this work, methods of estimation of road roughness by processing data of laser sensors of distance measurement are investigated. Depending on the layout of the sensors and the processing of the data, the Japanese, symmetrical and asymmetrical roughness estimation methods are elaborated in this work. The experimental research that was carried out by "Japanese method" on two known profile road surfaces allowed evaluating the influence of the vehicle's suspension and the body pitch rate oscillation on the calculation of the roughness. The validation of the results showed that the compensation of the suspension travel does not warrant the sufficient accuracy of the estimation of the road roughness because the pivoting of the bodywork has a greater influence on the processing of the signals recorded by the sensors attached to it.
\end{abstract}

Keywords: road roughness, laser sensor, pitch angle, suspension deflection.

\begin{abstract}
Artykut przedstawia i ocenia metody określania nierówności nawierzchni drogi na podstawie danych z laserowych czujników pomiaru odlegtości. W artykule omówiono opracowane w Japonii symetryczne i asymetryczne metody określania nierówności nawierzchni, które różnią się sposobem rozmieszczenia czujników i przetwarzania danych. Badania eksperymentalne przeprowadzone na podstawie „,metody japońskiej” na dwóch zadanych profilach nawierzchni pozwolity na ocene wptywu zawieszenia samochodu i zmian przechylu nadwozia względem osi podtużnej na obliczanie nierówności nawierzchni. Walidacja wyników pokazała, że kompensacja odchylenia zawieszenia nie zapewnia wystarczajacej dokładności pomiaru nierówności drogi, ponieważ przechyły nadwozia mają większy wpływ na przetwarzanie sygnatów rejestrowanych przez zamontowane na nim czujniki.
\end{abstract}

Stowa kluczowe: nierówności drogi, czujnik laserowy, przechyt (kąt) względem osi podtużnej, odchylenie zawieszenia.

\section{Introduction}

The road surface profile is one of the main parameters which influences the vehicle's road holding and comfort characteristics. When the car moves on a rough road surface, the recorded parameters of the road surface profile can be applied in improving the dynamic characteristics. One of the methods of improving the road holding is the changing of the suspension damping force by active or semi-active type shock absorbers. That would ensure better driving comfort, vehicle steerability and the overall road safety $[11,25]$. Then using active or semi-active suspension road irregularities are recorded then front wheel comes on bump or pothole. Therefore, road irregularities measurement with laser sensors lets preview roughness before wheel comes on it. It lets innovatively control suspension and gets better road holding and comfort characteristics.

Many methods are designed in order to determine the road disturbances. Some methods are based by the profilograph measuring device, others by profilometer [9]. Both methods are very expensive and are used only in road building and maintenance companies [5]. Also, a profilometer which consists of 30 aluminium arms is designed. The device measures a $3 \mathrm{~m}$ wide road surface and the measurements are done every $10.18 \mathrm{~mm}$ with the help of the arms [3]. It is widely used dynamometer trailer with measuring single wheel named SRT-4. Equipment is manufactured at Road and Bridge Research Institute, Poland [16]. With this trailer is able to investigate road surface adhesion and automotive tyre anti-slip properties [17].
A number of studies carried out to estimate road profile with factory-mounted sensors and using same filters and mathematical algorithms. Widely used Youla-Kučera parameterization technique also known as Q-parameterization [6]; Kalman filter [18]; Extended Kalman filter [4] and etc. Mathematical algorithms require very fast processing, because it requires additional calculations and precision still unmatched by direct measurement (laser, stereo camera, etc.).

Furthermore, there are methods to determine the road disturbances in standard cars by using additional devices, e.g., stereo camera which can scan the road surface and also forecast the disturbances by using the available sensors that are mounted in the car $[5,7]$.

Another method used to evaluate the road roughness is the International Roughness Index (IRI) [13, 14, 20]. IRI is an index defined by the number of disturbances, their size and layout per unit length of the road surface [22]. Scientist P. Mučka [14] is summarised IRI limit values for new, reconstructed, or rehabilitated roads and road classification schemes used around the world.

IRI index is calculated by simulating the quarter-car model, also known as Golden car, moving on the measured road profile at a speed of $80 \mathrm{~km} / \mathrm{h}$. The model allows to measure the displacements of the suspension and wheel, compensate them and evaluate the road profile. Also index could be measured using an instrumented vehicle equipped with non-contact sensors (infrared, laser or acoustic etc.) and accelerometers [1]. Different IRI values are supposed for different surfaces (Fig. 1). The measurement units for IRI are $\mathrm{m} / \mathrm{km}$, in $/ \mathrm{mi}$. 


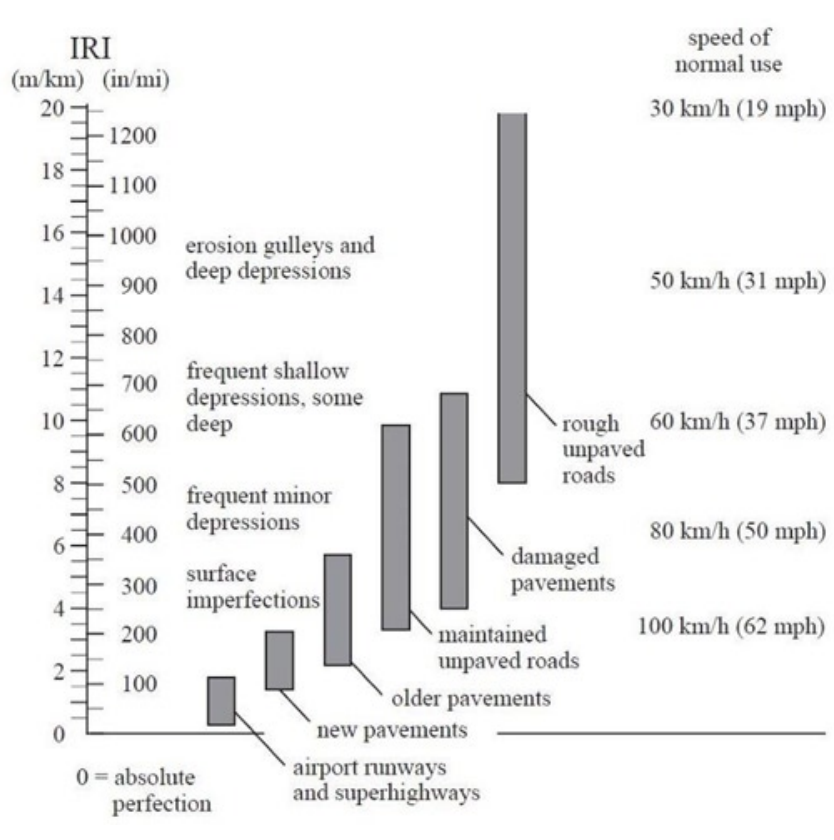

Fig. 1. IRI meanings depending on the road surface [20]

Another index describing the road disturbances is half-car roughness index (HRI). When determining this index, two wheel tracks and a dynamic model of the "half-car" are used. The IRI index correlates with the HRI index at an approximate ratio $H R I \approx 0.8$ IRI [19].

The aim of this work - after reviewing the road roughness estimation methods, to experimentally determine the road profile using the Japanese method and by applying the suspensions deflection and the body longitudinal roll compensation to improve the Japanese method.

\section{Review of existing methods}

Yuan et. al. [24] describes a method how to determine the road surface disturbances using laser line detection devices. The influence of the car and relief shadow on the accuracy of the measurement is described. It is stated that for the use of this method the road surface has to be clear. In the article [2], this method is applied to platooning of trucks. The first truck measures the road surface by lasers and transfers the obtained parameters to the following trucks. For the processing of the results, the Naïve Bayes method is used [12].

Another method to determine the road disturbances is to use the data of the car's acceleration $[8,15]$. During the moving of the car, the data from accelerometer are recorded, they are optimised and, based on The Cross Entropy theory, the road disturbances are forecasted. Many cars have factory mounted accelerometers because the active safety systems of the car use deceleration and acceleration meanings. The research which was carried out with 5 road surfaces showed that the forecasting of the road surface from the acceleration parameters is sufficiently accurate (error up to $\pm 2 \%$ ).

\subsection{Japanese method}

In Japan, in order to determine the road disturbances, a method measuring the height differences from the road surface is used (Fig. 2). The measurements are done every $1.5 \mathrm{~m}$ at three points. While doing the measurement, all the results are recorded, and to get better accuracy, lasers are used instead of rolls [21].

The recorded measurement results are processed using equation:

$$
d_{i}=h_{i}-\frac{1}{2}\left(h_{i-1}+h_{i+1}\right)
$$

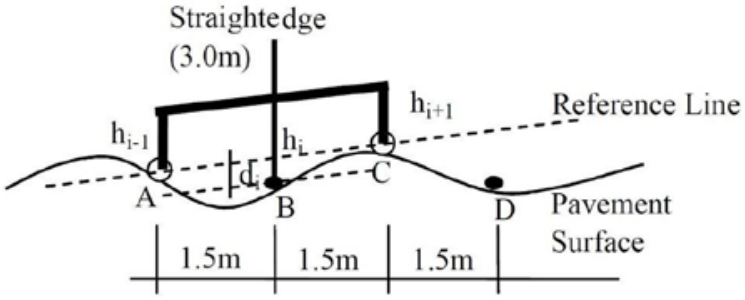

Fig. 2. The road roughness measurement method used in Japan [21]

Here $d_{i}$ - the roughness of the road profile; $h_{i}, h_{i-1}, h_{i+1}$ - the distances measured at characteristic points.

From the Fig. 2 It can be seen that after determining the roughness of the road profile $d_{i}$ at the point $\mathrm{B}$, the measurement point is shifted to position D, where the heights $h_{i}, h_{i-1}, h_{i+1}$ are respectively at the points $\mathrm{B}, \mathrm{C}$ ir $\mathrm{D}$. The baseline becomes a line, going through the points $\mathrm{B}, \mathrm{C}$ and $\mathrm{D}$. Using the equation (1) $d_{i}$ can be calculated at the point $\mathrm{C}$. After completing a group of measurements, positive and negative bump values are obtained. These bumps are height differences based on the baseline every $1.5 \mathrm{~m}$.

The standard deflection of the longitudinal roughness is calculated by summing the road profile heights by using the equation:

$$
\sigma=\sqrt{\frac{n_{r} \sum d_{i}^{2}-\left(\sum d_{i}\right)^{2}}{n_{r}\left(n_{r}-1\right)}}
$$

Here $\sigma$ - the standard deflection of the longitudinal roughness ( $\mathrm{mm}$ ); $\mathrm{d}_{\mathrm{i}}-$ the roughness of the road profile; $\mathrm{n}_{\mathrm{r}}-$ the number of the recorded date.

Japan Highway Public Corporation recommends to calculate the coefficient $\sigma$ from the recorded values of a road section of length of $150 \mathrm{~m}$.

\subsection{Symmetrical estimation method}

Two more methods for estimation of the road disturbances using laser sensors are described in the source [10]. The first one is the symmetrical estimation method (Fig. 3).

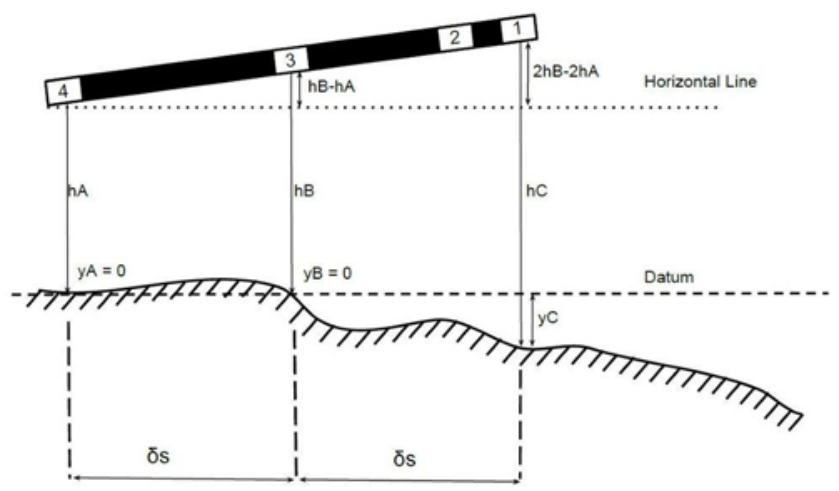

Fig. 3. The symmetrical road roughness estimation method [10]

This estimation method is more reliable when measuring the road roughness waves of $3 \mathrm{~m}$ and longer. The symmetrical method is similar to the previously mentioned Japanese method, however the laser sensors are arranged at the distance of $\sigma s=0.6 \mathrm{~m} \mathrm{~m}$. In Fig. 3, the laser distance sensors are marked by numbers $1,3,4$. After recording the data of the sensors, the roughness is calculated by using equations:

$$
y_{n}=y_{n-1}+\sum_{i=1}^{n} U_{i}
$$




$$
U=-\left(h_{1}-2 h_{3}+h_{4}\right)
$$

Here $y$ and $U$ indicate the average height at the distance of $\sigma s$.

\subsection{Asymmetrical estimation method}

The asymmetrical estimation method is used as a supporting method for the symmetrical one. This method is designed for determining the smaller waves of the road roughness. The system also uses

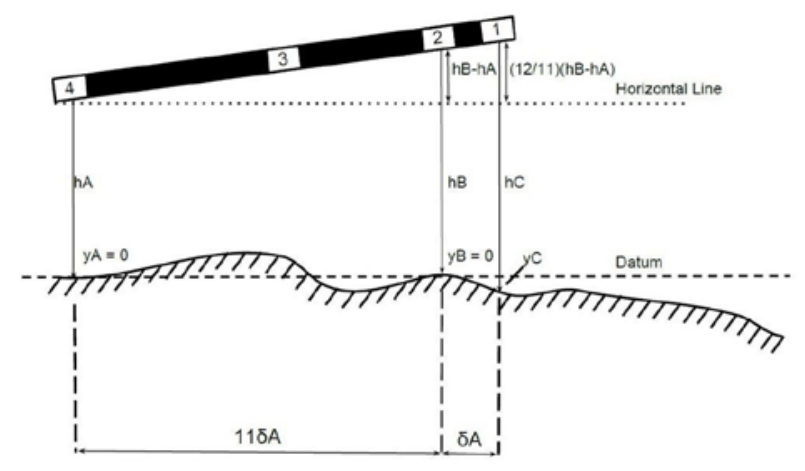

Fig. 4. The asymmetrical road roughness estimation method [10]

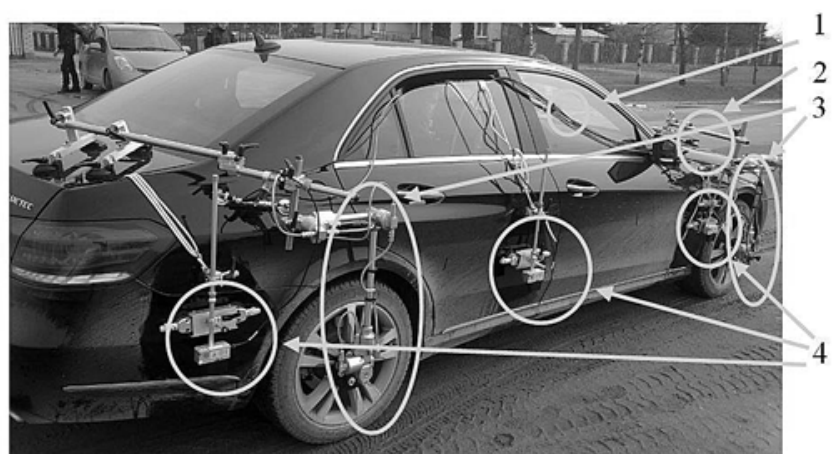

Fig. 5. A car with the mounted mobile Kistler Group measurement equipment

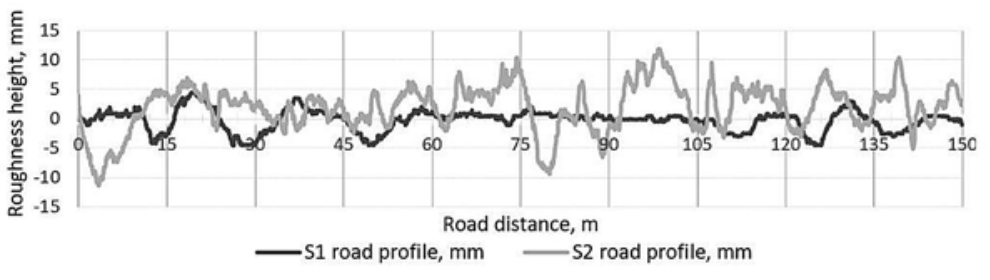

Fig. 6. The profiles of the road surfaces $S 1$ and $S 2$
3 laser sensors, only they are arranged asymmetrically (Fig. 4).

The distance between the sensors 1 and 2 is $\mathrm{m}$, the distance between the sensors 2 and 4 is $\mathrm{m}$. The recorded values of each sensor are used when calculating the road roughness average by using the equations:

$$
W=-\left(h_{1}-\frac{12}{11} h_{2}+\frac{1}{11} h_{4}\right)
$$

$$
y_{n}=\frac{12}{11} y_{n-1}-\frac{1}{11} y_{n-12}+W_{n}
$$

Here $y$ and $W$ indicate the average height and measurement parameters at the distance of $\sigma A$.

The presented road roughness estimation methods limit themselves to the processing of the signals measured by the laser distance to the road surface sensors, however when mounting the sensors on the car it is equally important to evaluate the inertia of the bodywork.

\section{Experimental Research}

Car Mercedes-Benz E350 BlueTec 4MATIC 2014 year is used for the research. The weight of the car during the research is $1956 \mathrm{~kg}$, the overall dimensions - length $4879 \mathrm{~mm}$, width $1853 \mathrm{~mm}$, height $1474 \mathrm{~mm}$, wheel base $2873 \mathrm{~mm}$, researched with tires of dimensions 245/45 R17. Recording the dynamic parameters, the mobile Kistler Group measurement equipment was mounted on the car: three distance measurement sensors Corrsys-Datron HF-500C (Fig. 5), two (for separate axes) wheel vector sensors Kistler $R V-4$, an optical velocity and driver distance measurement device Correvit S-350 Aqua, vehicle inertia measurement unit (IMU) Corrsys-Datron TANS-3. The technical parameters of the used equipment are presented in table 1.

All of the measured parameters were registered at the frequency of $200 \mathrm{~Hz}$ to Data Acquisition Systems $D A S-3$, and later processed on the computer by using the TurboLab 6.0 software.

Two dry asphalt road sections of length of $150 \mathrm{~m}$ were chosen for the experimental research. The profiles of the two selected different road surfaces are presented in the Fig. 6 . The largest deflection of the surface $\mathrm{S} 1$ is $4.8 \mathrm{~mm}$, and of the surface $\mathrm{S} 2-11.9 \mathrm{~mm}$ [26].

When carrying out the research, the car Mercedes-Benz E350 with the mounted equipment was driven at a steady speed of $80 \mathrm{~km} / \mathrm{h}$. When processing the research results, the calculations were done using 3 methods:

- The described Japanese method;

- The improved Japanese method - using only the values of $h_{i-1}$ and $h_{i+1}$, and compensating the suspension displacements (deflections) of the moving car;

- The improved Japanese method - using only the values of $h_{i-1}$ and $h_{i+1}$, and compensating the body pitch rate oscillations.

When improving the Japanese method, only the values of $h_{i-1}$, $h_{i+1}$ with the compensation of the suspension displacements were selected. In other case, the compensation the body pitch rate oscillations was added. The body pitch rate oscillation is described in the "halfcar" model (Fig. 7). 


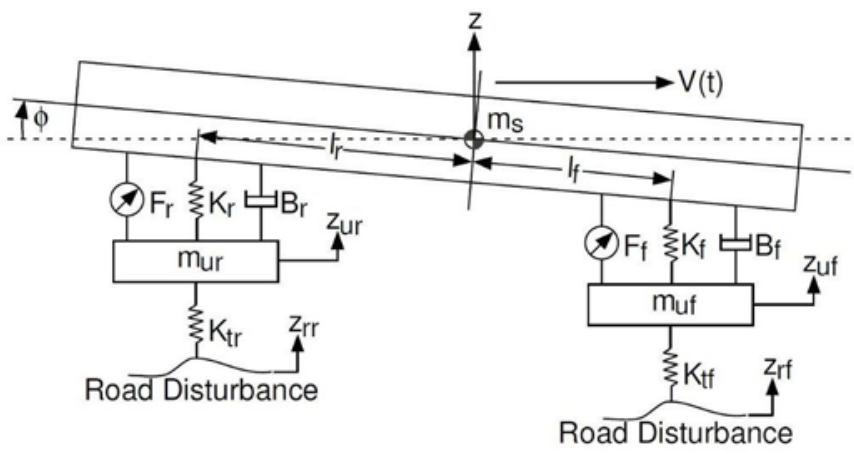

Fig. 7. "Half-car" model [23]

The "half-car" model consists of three bodies: $m_{s}$ - car's bodywork (sprung mass), $m_{u r}$ ir $m_{u f}$ - the front and rear wheels with axles (unsprung masses). This model has 4 degrees of freedom: the vertical displacement of sprung mass $z$ and transverse about the transverse axis $\phi$, the displacements of the unsprung masses $z_{u r}$ and $z_{u f}$. Independent excitations from the road are marked by displacements $z_{r r}$ and $z_{r f}$, the front and rear axles' suspension forces $F_{r}$ ir $F_{f}$.

The parameters in the "half-car" model are described by the Newton-Euler movement equations.

The vertical movement of the sprung mass:

$m_{s} \ddot{z}=-\left(B_{f}+B_{r}\right) \dot{z}+\left(l_{f} B_{f}-l_{r} B_{r}\right) \dot{\phi}-K_{f}\left(z_{r f}-z_{u f}\right)+B_{f} \dot{z}_{u f}-K_{r}\left(z_{s r}-z_{u r}\right)+B_{r} \dot{z}_{u r}+F_{f}+F_{r}$

The pivoting about the transverse axis:

$I \ddot{\phi}=\left(l_{f} B_{f}-l_{r} B_{r}\right) \dot{z}-\left(l_{f}^{2} B_{f}+l_{r}^{2} B_{r}\right) \dot{\phi}+l_{f} K_{f}\left(z_{s f}-z_{u f}\right)-l_{f} B_{f} \dot{z}_{u f}-l_{r} K_{r}\left(z_{s r}-z_{u r}\right)+$ $+l_{r} B_{r} \dot{z}_{u r}-l_{f} F_{f}+l_{r} F_{r}$

The movement of the front unsprung mass:

$m_{u f} \ddot{z}_{u f}=-K_{t f} z+B_{f} \dot{z}+l_{f} K_{t f} \phi-l_{f} B_{f} \dot{\phi}+\left(K_{f}+K_{t f}\right)\left(z_{s f}-z_{u f}\right)-B_{f} \dot{z}_{u f}-K_{t f} z_{t f}-F_{f}$

The movement of the rear unsprung mass:

$m_{u r} \ddot{z}_{u r}=-K_{t r} z+B_{r} \dot{z}-l_{r} K_{t r} \phi+\left(K_{r}+K_{t r}\right)\left(z_{s r}-z_{u r}\right)-B_{r} \dot{z}_{u r}+K_{t r} z_{r r}-F_{r}$

In the model, the values of the rigidity of the tire and the suspension $-K_{t f}, K_{t r}, K_{f}$ ir $K_{r}$, as well as the values of the suspensions damping $B_{f}-B_{r}$ ir are used.

In this work, the compensation of the body pitch while improving the Japanese method is used. For this goal, the displacement of the bodywork to the front and rear axles, which is formed by the pivoting around the transverse axis, is calculated (Fig. 7):

$$
\begin{aligned}
\Delta z_{r} & =l_{r} \cdot \tan \phi \\
\Delta z_{f} & =l_{f} \cdot \tan \phi
\end{aligned}
$$

Each $\Delta$ value is compensated from at the same time measured values of $h_{i-1}, h_{i+1}$.

\section{Results and discussion}

After processing the measured data using 3 described methods, the obtained results are presented in the Fig. 8. and Fig. 9. For better comparison of the methods, the results of one road section are shown in the same graph.

In order to evaluate the methods even more accurately, the validation based on the root mean squared error was used. The validation was done with the MATLAB software, and the results are presented in the Table 2 . The method most accurately matches the road profile when the body pitch rate oscillation is compensated. Validating by using this method, the root mean squared error is the lowest in the section $\mathrm{S} 1-0.5728$, and in the section $\mathrm{S} 2-2.4538$. The Japanese method dies not fully reflect the road profile because, when doing the calculations using the 1 equation, the average of the measured heights
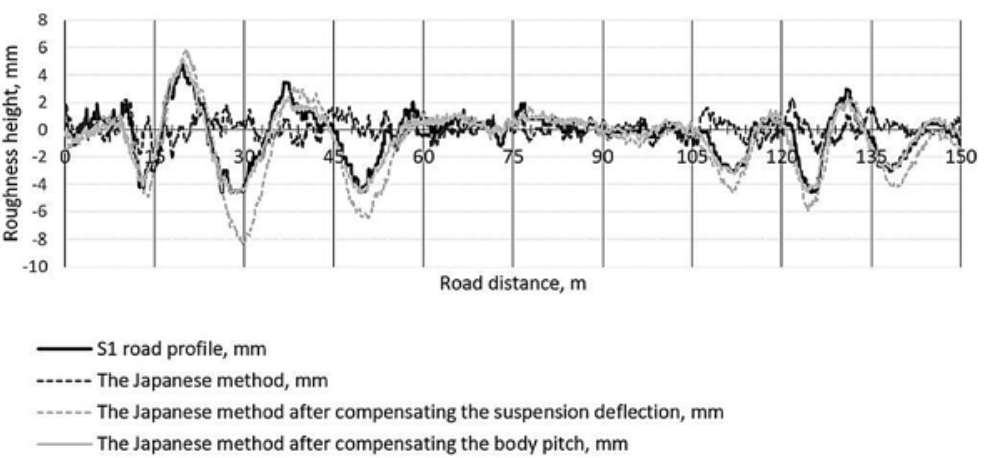

Fig. 8. The road profile determined by using three methods compared to the real road profile of the section $S 1$.

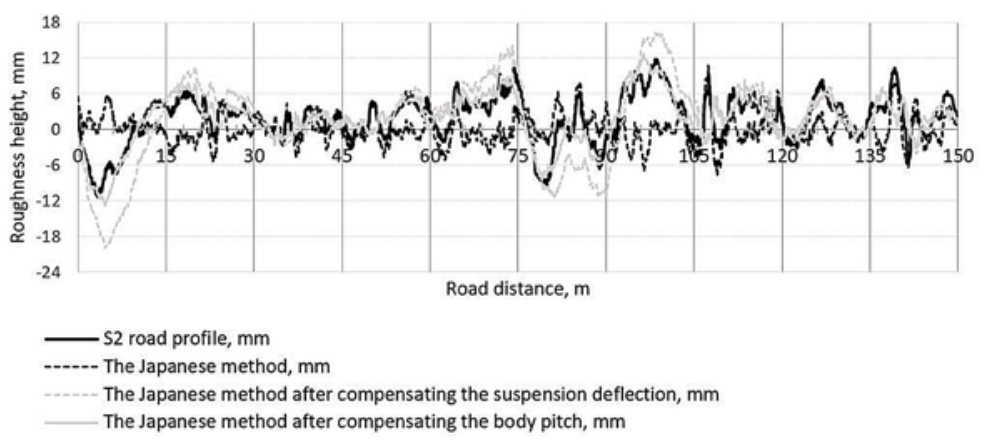

Fig. 9. The road profile determined by using three methods compared to the real road profile of the section $S 2$

Table 2. The results of the validation of the road roughness estimation methods.

\begin{tabular}{|l|c|c||}
\hline \multirow{2}{*}{ Measurement method } & \multicolumn{2}{|c}{ Validation based on the Root Mean Squared } \\
\cline { 2 - 3 } & \multicolumn{1}{|c||}{ S1 section } & S2 section \\
\hline The Japanese method & 1.9428 & 4.7157 \\
\hline The Japanese method after compensating the suspension deflection & 1.2804 & 4.2886 \\
\hline The Japanese method after compensating the body pitch rate oscillations & 0.5728 & 2.4538 \\
\hline
\end{tabular}


and by the side sensors is subtracted from value of the height of the middle sensor.

The improved Japanese method - using only the $h_{i-1}$ and $h_{i-+}$ values and by compensating the displacement of the suspensions for the moving car is not a sufficiently accurate method to determine the road surface. Moving through the road disturbances the car oscillates and the suspension damps the oscillations of the bodywork, that is why the displacement of the suspension is compensated, which is larger than the actual road disturbance.

\section{Conclusion}

After reviewing the road roughness estimation methods using the laser distance sensors and carrying out the experimental research with the sensors mounted on a standard car, the following conclusions were made:

- the widely applied Japanese method for the practical estimation of the road roughness based on the data of the three laser distance sensors arranged at the distance of $1.5 \mathrm{~m}$ is not sufficient when the sensors are mounted on the bodywork of a standard car;

- when determining the road disturbances based on the data of the laser distance sensors mounted on a car, correction based on the suspension travel is not sufficient as it does not eliminate the oscillations of the bodywork;

- after applying the compensation of the body pitch rate oscillations, the best results of the road surface roughness was obtained, and, after validating it, based on the real road profile in road sections of different smoothness, the root mean squared errors that are lower from 1.92 to 3.39 times are obtained. After applying the less effective compensation of the suspensions travel, the root mean squared errors are lower only 1.1-1.52 times.

\section{References}

1. Ahmed A, Saeed T U, Labi S. Estimation of rest periods for newly constructed reconstructed pavements, Transport 2016; 31(2): 183-191, https://doi.org/10.3846/16484142.2016.1193050.

2. Aki A, Rojanaarpa T, Nakano K, Suda Y, Takasuka N, Isogai T, Kawai T. Road Surface Recognition Using Laser Radar for Automatic Platooning. IEEE Transaction on intelligent transportation systems 2016; 17(10): 2800-2810, http://dx.doi.org/10.1109/TITS.2016.2528892.

3. Becker C, Els S. Profiling of rough terrain. International Journal of Vehicle Design 2014; 64: 240-261, http://dx.doi.org/10.1504/ IJVD.2014.058500.

4. Castillo Aguilar J J, Cabrera Carrillo J A, Guerra Fernández A J, Carabias Acosta E. Robust Road Condition Detection System Using InVehicle Standard Sensors, Sensors 2015; 15(12): 32056-32078, https://doi.org/10.3390/s151229908.

5. Doumiati M, Erhart S, Martinez J, Sename O, Dugard L. Adaptive control scheme for road profile estimation application to vehicle dynamics. The International Federation of Automatic Control 2014: 8445-8450, http://dx.doi.org/10.3182/20140824-6-ZA-1003.00986.

6. Doumiati M, Martinez J, Sename O, Dugard L, Lechner D. Road profile estimation using an adaptive Youla-Kučera parametric observer: Comparison to real profilers, Control Engineering Practice 2015: 1-9, http://dx.doi.org/10.1016/j.conengprac.2015.12.020.

7. El-Ashmawy K L A. A simple technique for road surface modelling, Geodesy and Cartography 2016; 42(3): 106-114, http://dx.doi. org/10.3846/20296991.2016.1226392.

8. Harris N K, Gonzalez A, O`Brien E J, McGetrick P. Characterisation of pavement profile heights using accelerometer readings and a combinatorial optimisation technique. Journal of Sound and Vibration 2010, 329: 497-508, http://dx.doi.org/10.1016/j.jsv.2009.09.035.

10. Kilic F, Hilsmann J. Application and Improvement of the TRRL (Transport and Road Research Laboratory) High-Speed Laser Profilometer Algorithm with Sensor Fusion. IFAC (International Federation of Automatic Control) Papers On Line 1966; 49-15: 260-265, http://dx.doi. org/10.1016/j.ifacol.2016.07.761.

11. Levulytė L, Žuraulis V, Sokolovskij E. The research of dynamic characteristics of the vehicle driving over road roughness. Eksploatacja i Niezawodnosc - Maintenance and Reliability 2014; 16(4): 518-525.

12. Martinez-Arroyo M, Enrique S L. Learning an Optimal Naive Bayes Classifier. The 18th International Conference on Pattern Recognition 2006, http://dx.doi.org/10.1109/ICPR.2006.748.

13. Múčka P. Current approaches to quantify the longitudinal road roughness, International Journal of Pavement Engineering 2016; 17(8): 659-679, https://doi.org/10.1080/10298436.2015.1011782.

14. Múčka P. International Roughness Index specifications around the world, Road Materials and Pavement Design 2016: 1-37, https://doi. org/10.1080/14680629.2016.1197144.

15. O`Brien, E J, McGetrick P, Gonzalez A. Identification of Road Irregularities via Vehicle Accelerations. Transport Research Arena Europe 2010.

16. Pakorski j, Reński A, Sar H. System for investigation of friction properties of the road surface, The Baltic Journal of Road and Bridge Engineering 2015; 10(2): 126-131, https://doi.org/10.3846/bjrbe.2015.16.

17. Raslavičius L, Pakalnis A, Keršys A, Skvireckas R, Juodvalkis D. Investigation of asphalt texture roughness on friction evolution for wheeled vehicles. Transport 2016; 31(2): 133-141, http://dx.doi.org/10.3846/16484142.2016.1189960.

18. Sahlholm P, Jansson H, Kozica E, Johansson K H. A sensor and data fusion algorithm for road grade estimation, 5th IFAC Symposium on Advances in Automotive Control 2007; 40(10): 55-62, http://dx.doi.org/10.3182/20070820-3-US-2918.00010.

19. Sayers M W. Two Quarter-car models for defining road roughness IRI ir HRI. Transportation Research Record 1989; 1215 : $165-172$.

20. Sayers M W, Karamihas S M. The Little Book of Profiling. Basic Information about Measuring and Interpreting Road Profiles. Michigan 1998.

21. Souza R O, Neto S D, Farias M M. Improving Pavements With Long-Term Pavement Performance: Products for Today and Tomorrow. Papers From the 2003-2004 International Contest on Long-Term Pavement Performance Data Analysis 2006: 5-6.

22. Tomiyama K, Kawamura A. Application of lifting wavelet transform for pavement surface monitoring by use of a mobile profilometer. International Journal of Pavement Research and Technology 2016; 9(5): 345-353, http://dx.doi.org/10.1016/j.ijprt.2016.08.007.

23. Vaughan J E. Active and Semi-Active Control to Counter Vehicle Payload Variation. A thesis, The George W. Woodruff School of Mechanical Engineering, George Institute of Technology 2004. 
24. Yuan Z, Zhang X, Liu S, Han X, Du Y. Laser Line Recognition for Autonomous Road Roughness Measurement. The 5th Annual IEEE International conference on Cyber Technology in Automation, Control and Inteligent Systems 2015: 436-440, http://dx.doi.org/10.1109/ CYBER.2015.7287977.

25. Žuraulis V, Levulytė L, Sokolovskij E. The Impact of Road Roughness on the Duration of Contact Between a Vehicle Wheel and Road Surface, Transport 2014; 29(4): 431-439, http://dx.doi.org/10.3846/16484142.2014.984330.

26. Žuraulis V, Pečeliūnas R, Jakutis G. Semi-active suspension influence on comfort sensation of a vehicle occupant. Agricultural Engineering, Research Papers 2014; 46(1): 116-124, https://doi.org/10.15544/ageng.2014.011.

\section{Vytenis SURBLYS}

Vidas ŽURAULIS

Edgar SOKOLOVSKIJ

Department of Automobile Transport

Vilnius Gediminas Technical University

Basanavičiaus str., 28 LT-03224 Vilnius, Lithuania

E-mails: vytenis.surblys@vgtu.lt, vidas.zuraulis@vgtu.It, edgar.sokolovskij@vgtu.It 